\title{
SOLDIERS' CAREERS IN THE ROYAL ARMY MEDICAL CORPS AND ROYAL ARMY DENTAL CORPS *
}

\author{
Colonel A. B. DICK, T.D., M.B., Ch.B., D.T.M.\&H., Late R.A.M.C. \\ Medical Services \& W.R.A.C. Records, Winchester
}

SUMMARY: The entire structure of the Army is undergoing change to streamline itself for the Seventies. A review of Soldiers' Careers is part of the process and not least in the Army Medical Services.

This paper discusses the implications, particularly for the R.A.M.C., of the change in emphasis from seniority to merit as the main criterion for the promotion of soldiers, and outlines the new trade structure envisaged.

\section{Introduction}

At the time of writing, the Third Report of the National Board of Prices \& Incomes (N.B.P.I.) on the military salary, job evaluation within the Services and the banding of Army trades, has not been published. Nevertheless, it is believed that the changes foreseen are in line with the likely proposals of the N.B.P.I.

I have been asked to speak about careers for male soldiers in the Army Medical Services. My aim is to outline recent and proposed changes in general policy and to show how they affect the soldier.

\section{Career}

In my view a career is a form of employment over a number of years which brings mental and physical satisfaction and, at the same time, offers reasonable progression in both status and remuneration. If we speak of a "full career" then we must extend the definition to include also adequate pension rights on termination of employment.

Provided that our selection procedure and recruit training are good, then the primary requirements of mental and physical satisfaction should be met; equally, provided the military salary and the arrangements for its review are adequate, questions about remuneration should not arise.

This leaves, as the main concern of the Officer-in-charge (O.I.C.) Records, the Technical Training Officer (T.T.O.), and our various schools of instruction, the necessity to ensure reasonable progression in status through rank and trade, and it is these aspects about which I wish to speak more particularly today.

\section{8 and before}

The first step on any ladder is the most important and our study should therefore begin with the method of promotion to Lance Corporal (L cpl.). Up to 1968 O.I.C. Medical Services Records had two main guide rules for promotion. The first was in The Queen's Regulations for the Army (1961) which reads: "Selection will normally be based on seniority tempered by merit" and then having listed the "qualifications for promotion "-educational, military and trade-requires these to be published in detail in " Regimental or Corps Orders". The second source of guidance was Standing Orders (1952) for the R.A.M.C. and R.A.D.C. These are virtually identical and state

* As presented at the Director-General of Army Medical Services Study Period, December 1969. 
"Promotion .... is awarded for merit and competence in the technical and general duties of the Corps .... . seniority alone gives no claim to promotion ".

Effect was given to the pious hope that merit would carry the day over seniority by the inclusion in our Standing Orders (S.O.) of a system of priorities for promotion, based on educational and trade status. This was done for each group of ranks-the junior Non-commissioned Officer (N.C.O.), the senior N.C.O., and Warrant Officer (W.O.). Within this system the requirements at S.O. paragraph 434 for promotion on Priority I to L cpl., R.A.M.C. are, in addition to passing a corporal's (cpl.s) course, the attainment of the Army Certificate of Education (A.C.E.) Class II and a Class II trade; while Priority II for promotion requires the A.C.E. Class III and a Class III trade. May I add, on reflection, that in 30 years $I$ have not yet known any candidate R.A.M.C. on Priority II become a substantive L cpl. in peace time. So, perhaps there was some merit in the Merit system. Unfortunately the effect of this weeding out by priorities (if weeding out it was) was completely nullified by the preceding paragraph 433 of S.O. which states: "A Private (pte.) who has passed the cpl's course will be placed by O.I.C. Records on the roster for promotion for which he is qualified" (n.b. One roster for Priority II, another for Priority I). The paragraph continues: "His position in his priority will be governed by his date of enlistment": thus seniority again rears its ugly head, but worse is to follow when it states: "A L cpl. will similarly be placed by O.I.C. Records on the roster for promotion to cpl. in the priority for which he is qualified. His position will be governed by his seniority as $L$ cpl.".

The effect of these reservations was that a soldier who was slow to achieve Priority I for promotion to $\mathrm{L}$ cpl. but eventually managed to reach it after many years, shot to the top of the selection list, because of his long service. On doing so he passed on the way all the brighter younger soldiers who had worked harder and qualified before him but had not yet been selected simply because of lack of vacancies. Worse still, this same plodding $\mathrm{L}$ cpl. was enabled to do the same thing again as soon as he had slowly and painfully gained the qualification for full $\mathrm{cpl}$. His place on the cpls. roster once achieved, all he had to do to ensure certain promotion to get higher rank was to keep free of disciplinary charges, gain the basic qualifications for promotion and wait for dead men's shoes. That was the sad and sorry picture until two years ago.

In $1966 / 1967$ prospects were, to put it bluntly, pretty desperate. It was taking six years to become a substantive L cpl. R.A.M.C. in the non-technical trades and over twenty years to become a substantive W.O. on the general roll of the corps.

A major effort was made by an Army Medical Directorate (A.M.D.) working party to solve this difficulty of delay at least to the first rung of the promotion ladder by obtaining an overall increase in the number of $\mathrm{L} \mathrm{cpl}$. posts. This failed because the official view was then, and indeed still continues to be, that with the exception of the technical trades with their inbuilt time promotion structure all promotion must be based on the responsibilities of individual posts. An increase in $\mathrm{L}$ cpls therefore could be achieved only by amendments to unit establishments. The requirements of a career structure were not held to justify any allocation of higher ranks for soldiers on the general roll of the R.A.M.C. and indeed this is still so today although there is a slight difference here between R.A.M.C. and R.A.D.C. The latter, because of its small overall size and the difficulties of assessing responsibility for each chairside appointment, is given ranks on a percentage basis within its three trades. Subject to certain designated 
posts being filled by appropriate ranks and trades there is a small amount of leeway in the distribution of the rest of its quota.

However, one minor reform was achieved for R.A.M.C. From 1 June 1967 it was agreed that the order in which a pte. would be placed on the roster of those qualified for promotion to $\mathrm{L}$ cpl. would be decided not by date of enlistment, but by date of completion of qualifications. This change ensured that the brighter soldier would become a L cpl. more quickly than the less bright, but I must emphasise that this in no way reduced the length of time still required before the average soldier achieved his first substantive stripe.

\section{8 and after}

Enough of the past. In mid 1968, a keen fresh wind of change swept through the entire Service with the publication of Defence Council Instructions (Army), No. 194 of that year, entitled "Careers: Soldiers' Career Planning." This instruction covered four main subjects:-

First. It introduced for all new entrants to the Service control points at 9 and 12 years in addition to the 3 year and 6 year controls already existing in Queen's Regulations (Q.Rs).

Second: It amended Q.R. 1961 so that, from 1 October 1968, promotion would be by selection "by merit tempered by seniority" instead of the former "seniority tempered by merit".

Third. A more comprehensive system of confidential reporting was introduced.

Fourth. It foreshadowed a new system of career planning from the end of 1969.

I would like to deal with each of these points.

\section{Control of prolongation}

From the introduction of the 22 year engagement until the passing of the 1968 Army Act, all normal Army engagements had been for 6 years (in a few special instances only, for 3 years). The soldier had the option of prolonging his service to 9 years in the first instance, and subsequently, by 3 year periods or longer to complete 22 years. By so doing he gained higher rates of pay.

At each 3 year poini the soldier (subject to 6 months' notice) could opt to leave the service, and in the absence of a military emergency could not be retained unless he had, by attending one of a few special long-term courses, become time-barred for a limited period. The Service on the other hand, unless it chose to discharge him at the 3 or 6 year point as " not required for further Army service", could not later refuse the soldier's repeated prolongations unless his behaviour was so bad as to justify discharge for misconduct or similar reasons, or alternatively he was declared redundant and given his discharge, together with rather handsome compensation for "loss of office".

The individual soldier could go or stay as he chose, although the Army, after the $5 \frac{1}{2}$ year point (allowing for 6 months notice) had no such choice.

This was altered by the 1968 Army Act for all enlistments on and after 19 June of that year. The new terms of engagement were amended to extend the Army's choice beyond the 6 year point to include the 9 and 12 year points: these were in effect 8 and 
11 year points, because a year's notice has then to be given. Obviously, a minimum of 8 years from 1968 until 1976 must elapse, before the scheme first becomes effective, since it applies only to new enlistments. Nevertheless, from 1976 onwards the Army will be able to give soldiers notice to go at the 9 or 12 year points if for any reason a full 22 year career cannot be foreseen for them. The present redundancy system will not need to be used in such cases, and compensation will not be paid.

Merit. Now for the second and to date, the main reform initiated by the Defence Council Instruction (D.C.I.) the change whereby Merit becomes the most important criterion for promotion.

On studying details of the new scheme it is evident that seniority is still of importance as the major method of deciding entry into a "Promotion Zone". A recommendation for accelerated advancement is an equally effective method of entry to the zone provided the Promotion Board considers that recommendation to be justified.- Thereafter, "selection for promotion" and I quote " selection from within the Zone will be entirely on merit". Further, this selection is to be done by a formally appointed "Promotion Board".

The size of any promotion zone-the system covers all ranks above $\mathrm{L}$ cpl.--has been agreed between A.M.D. and Records as three times the number of vacancies which are to be filled, provided of course, that there are so many candidates qualified and recommended. A minimum of six names is considered if there are only one or two vacancies to be filled.

It has been agreed also that even if there are sufficient candidates, if the Promotion Board is not satisfied with the standards of those candidates, vacancies can be left unfilled until more suitable candidates are available.

The other main factor in relation to higher rank, is the time taken to achieve it. As I have already stated, two years ago prospects were "pretty desperate". It was then taking an average of over six years to become a $\mathrm{L}$ cpl. however quickly a soldier qualified for that rank, and over twenty years to become a substantive W.O. on the general roll of the Corps.

Various measures proposed to ameliorate or improve the situation were of no avail. Outside the technical trades which have advancement by time, all promotion must be based on responsibility of posts. The requirements of a career structure of itself are not held to justify higher rank for any soldier on the general roll of the R.A.M.C.

However, a way has been found to ease the immediate situation. The numbers of substantive promotion vacancies in the Medical Services are decided on a quota of ranks allocated by Ministry of Defence (M.O.D.). Until this present year (1969) it was permissible to appoint to substantive ranks only up to 90 per cent of authorised strengths, the balance being filled by acting ranks within unit establishments. This gave mobility and flexibility or postings without any grave financial loss, since all acting tank is paid and any paid acting rank in the last five years of service counts equally towards pension. However, it did leave greater numbers of soldiers exposed to the hazards of acting rank, and it also reduced the numbers of vacancies on the first rung of the substantive promotion ladder ( $\mathrm{L} \mathrm{cpl.).}$

In June 1969, it was agreed that of the quota, up to 95 per cent (instead of 90) of seniors could be given substantive promotion and up to 97 per cent of lower ranks. 
This, allowing for minor adjustments due to establishment changes, has given an increase of over 140 substantive ranks, greatly improving the chances of a pte. to be promoted to substantive $\mathrm{L}$ cpl.

Thereafter, the principle of selective promotion on merit means that the more efficient soldier advances in rank more quickly than his less efficient colleague once he has achieved that basic step of appointment to substantive $\mathrm{L}$ cpl.

It is of interest that out of a total strength of 3470 R.A.M.C. in 1970, the new rank quota authorises 1795 substantive W.Os and N.C.Os in the non-technical trades and at least a further 232 ranking technicians, together amounting to 58.4 per cent of the entire R.A.M.C. This is of course by no means the whole picture, since, if acting ranks are included we find that there were on 30 September 1969 no less than 2110 WOs. and N.C.Os out of an overall R.A.M.C. strength of 3339, or 63 per cent of the effectives. In other words, just short of two chiefs for every Indian in the Corps. For the R.A.D.C. the quota ranks allowed are 286 W.Os and N.C.Os. With only 54 ptes. in the Corps or 84.4 per cent W.Os and N.C.Os, no less than five chiefs for every Indian (Table I).

Table I

Strengths by paid ranks 30 September 1969

\begin{tabular}{l|c|c|c|c}
\hline \multirow{2}{*}{ Ranks } & \multicolumn{2}{c|}{ R.A.M.C. } & \multicolumn{2}{c}{ R.A.D.C. } \\
\cline { 2 - 5 } & Numbers & Percentage & Numbers & Percentage \\
\hline Warrant Officers & 250 & & 23 & \\
Senior Non-Commissioned Officers & 831 & & 122 & \\
Junior Non-Commissioned Officers & 1029 & & 147 & \\
\hline Totals & 2110 & 63 & 292 & 84.4 \\
Privates & 1229 & 37 & 54 & 15.6 \\
\hline Totals & 3339 & 100 & 346 & 100.0 \\
\hline
\end{tabular}

Admittedly there is a price to be paid and that is now undergoing examination. As the outstanding and the very good, will always (or almost always) rise to the top more quickly, the good average who thoroughly deserves promotion in his turn, may tend to be pushed back little by little at each successive promotion hurdle. Our aim at Records must be to ensure; first and foremost, that reporting officers are fully aware of the importance of the soldier's Annual Confidential Report and do not 'cheat'. Secondly, that the period required by this same "good average soldier" to attain a rank shall be in reasonable agreement with the "ideal periods" recommended by the Committee on the Structure of the Army (C.O.S.A.) as giving a good career. Thirdly, that there shall be reasonable agreement between the average rates of advancement to higher rank in the various sections of the Corps, particularly to the stage of W.O. and the chance of appointment to a regular Quartermaster Commission.

Revised Annual Confidential Report 1968 pattern. The form of this report is already familiar to you all. It now incorporates various headings which are given mathematical values and therefore "Lord help us!" amenable to statistical sorting and analysis by computers, a fashionable process nowadays. This O.I.C. Records has already submitted, the most earnest plea that any preliminary sorting by computer must be regarded as highly premature. 
Gentlemen I must emphasise my earlier remark that reporting officers must play fair. But, can " cheating" occur? My first illustration is at the lowest end of the scale. A young or relatively inexperienced officer is in charge of a small department or detachment and is required to fill in Part 1 on members of his staff. He dislikes unpleasantness - who doesn't - and rather than give a true adverse picture of some N.C.O. or man he doesn't like and with whom he may have had difficulties, he writes a better than average report so that he does not appear biassed. He hopes the subject will respond accordingly or be promoted out of his department. Alternatively, because of his inexperience he allows himself to be influenced unduly by a strong-minded W.O. or senior N.C.O. who persuades this young reporting officer to mark him as "well above average" or even " outstanding ". Gentlemen, you know this happens in your Commands and Districts, we see it nearly every day in Records. We call it the "Big Frog" technique.

The pious intention of those who drafted the new form (and the accompanying instructions on Army Form B2048A are quite clear), is that Part 1 of such a report should be amended by the next higher officer in the chain of reporting, usually the Commanding Officer (C.O.) when he completes Part II, or, if necessary, by the Senior Medical Officer/Assistant Director of Medical Services/Deputy Director of Medical Services at Part III. Unfortunately, often this is not done and we have to assess from the C.O's remarks whether Part I is or is not over-marked (or in the much rarer case, undermarked).

A second instance in which over-marking occurs is again in a limited community, but here the offenders are more senior officers and the size of the community concerned is dictated usually by a common interest; this can happen in a hospital or company office, an operating theatre, or even a whole unit provided it is fairly small and has a specialist role. Because of this common interest and the close daily association within the group, all members become swans. There are no geese and seldom even a duck, except perhaps some unfortunate who has just recently joined the group and whose face does not fit.

Gentlemen, have you ever wondered why so high a proportion of our W.Os and senior N.C.Os at regimental duty are Clerks by trade? Throughout their entire careers they work close to you. They read the new regulations a few days before you do, so that when you ask for some information, there it is-all ready. They not only anticipate your wishes, they even bring your mid-morning tea! Of course, they are " outstanding" and are reported on as such. Today their promotion under the new system cannot be gainsaid. As a result, for 28 clerical appointments for W.Os in the R.A.M.C., there are 55 substantive ranks to fill them.

Please-please-please! May I ask you to look carefully at every report which comes to your notice. I make here a very strong personal plea that each of you will try to impress on Reporting Officers that these reports should be completed against a Corps background, not just our office, our department, our special interests, our present unit or Command. I say "a personal plea" gentlemen because I personally have read every report written on the new form on every member of the R.A.M.C. and R.A.D.C. which has yet reached the Record Office. This has been because I believe the new system of promotion, based on use of these new forms, is one of the most. important reforms the Army has ever known. But its success depends entirely on the honesty, the fairness and the integrity of the reporting officers. 
I mentioned the Promotion Board which consists of four members-the Colonel Commanding an independent unit, currently 4 Company, Netley, a representative from A.M.D. 2, the Retired Officer in Records specifically charged with the responsibility for trades and promotions, and myself in the Chair.

As of today we must muster between us 128 years service and it is simply and solely because of this wide spread of experience and personal knowledge of reporting officers, that we are able to tackle the job of standardising reports and thereafter selecting for promotion.

This is no small task. By 30 June in this year (1969) alone we had made 472 actual substantive promotions R.A.M.C./R.A.D.C. under the new system, and since then over 400 more. The substantive promotions by rank made during 1969 are given in Table II.

Table II

Substantive promotions 1 January to 31 December 1969

\begin{tabular}{|c|c|c|c|c|c|c|}
\hline \multirow{2}{*}{ Promotion to } & \multicolumn{2}{|c|}{ R.A.M.C. } & \multicolumn{2}{|c|}{ R.A.D.C. } & \multirow{2}{*}{ Q.A.R.A.N.C. } & \multirow{2}{*}{ Totals } \\
\hline & $\begin{array}{l}\text { General } \\
\text { roll }\end{array}$ & Technicians & $\begin{array}{c}\text { General } \\
\text { roll }\end{array}$ & Technicians & & \\
\hline $\begin{array}{l}\text { Warrant Officer I } \\
\text { Warrant Officer II } \\
\text { Staff sergeant } \\
\text { Sergeant } \\
\text { Corporal } \\
\text { Lance corporal }\end{array}$ & $\begin{array}{r}13 \\
43 \\
73 \\
129 \\
216 \\
326\end{array}$ & $\begin{array}{r}2 \\
11 \\
5 \\
11 \\
6 \\
9\end{array}$ & $\begin{array}{r}2 \\
3 \\
1 \\
\\
4 \\
14\end{array}$ & $\begin{array}{l}3 \\
2 \\
2\end{array}$ & $\begin{array}{r}2 \\
3 \\
24 \\
24\end{array}$ & $\begin{array}{r}17 \\
57 \\
81 \\
146 \\
252 \\
375\end{array}$ \\
\hline Totals & 800 & 44 & 24 & 7 & 53 & 928 \\
\hline
\end{tabular}

With such a rate of promotions Gentlemen, the use of a recommendation for accelerated advancement becomes more than a potent weapon. It could be a disaster to the man who progresses too quickly now, only to crash later. Equally, its over use will hold back good middle standard soldiers who deserve a full career, and finally if still over used it will nullify its own value.

It is for your earnest consideration Gentlemen, that no soldier should be recommended for accelerated advancement to the next rank until he had held his present rank for at least one, or perhaps even two years. From this I would exclude only the L cpls:

What are the so-called ideal speeds and how do the R.A.M.C./R.A.D.C. stand in comparison. These are shown in Table III and highlight my last point.

Table III

Speeds of promotion (non-technicians) in years of service

\begin{tabular}{|c|c|c|c|c|c|}
\hline \multirow{2}{*}{ Ranks } & \multicolumn{2}{|c|}{ C.O.S.A. Recommendations } & \multicolumn{2}{|c|}{ R.A.M.C. } & \multirow{2}{*}{$\begin{array}{l}\text { Range of service } \\
\text { of appointees }\end{array}$} \\
\hline & Ideal & Normal limit & $1967 / 1968$ & 1969 & \\
\hline $\begin{array}{l}\text { Warrant Officer I } \\
\text { Warrant Officer II } \\
\text { Staff sergeant } \\
\text { Corporal } \\
\text { Lance corporal }\end{array}$ & $\begin{array}{c}19 \\
16 \\
14 \\
6 \\
\text { Regimental }\end{array}$ & $\begin{array}{r}20 \\
17 \\
15 \\
7 \\
\text { discretion }\end{array}$ & $\begin{array}{c}20^{2} / 12 \\
20^{5} / 12 \\
13 \% / 12 \\
6^{9} / 12 \\
6^{2} / 12\end{array}$ & $\begin{array}{l}16^{6} / 12 \\
14^{5 / 12} \\
13 \\
5^{3} / 12 \\
5^{2} / 12\end{array}$ & $\begin{array}{r}13-20 \\
11-20 \\
9-19 \\
3-19 \\
1-13\end{array}$ \\
\hline
\end{tabular}




\section{The new career structure}

Is it right that a soldier should advance much more quickly in one trade than in another in the same Corps? One must allow first of all for the division into technicians and non-technicians. The former-and this includes dental technicians for promotion, though not for technical rates of pay-have an inbuilt system of time promotion based on trade status and experience. Except for the Public Health Inspector, who is classed as a supervisory technician, this time promotion works only up to the rank of sgt. and normal selection procedure within the trade concerned comes into use thereafter for higher ranks. But at least these technicians know that simply by producing good quality work they will achieve the Sergeants' Mess, generally speaking within five years of qualifying in their trade.

Here I should interpolate that in the near future, I hope to see classified with the other technicians the male State Registered, General and Mental Nurses who-and I emphasise that this is a personal view-have received less favourable treatment than their qualifications deserve for far too long.

The speeds of promotion for the non-technicians including until now the nurses, have applied across the whole range of trades since all have been promoted within the general roll of the R.A.M.C. But this same Defence Council Instruction (Army) 194 of 1968, lays down that the M.O.D. personnel branch and the Record Office for each Arm should examine its structure and sub-divide its soldiers into "Trade Rolls" each of which, within certain reasonable limits, should be self contained and offer a worth while career to the man who stays in that trade group throughout his Army service.

May I say here that the R.A.D.C., always to the forefront in progress, has been separated into the three trades of Dental Clerk/Assistant (D.C.A.), Dental Technician and Dental Hygienist, each in its respective trade roll, for some years. Although the D.C.A. is the basic trade of that Corps and the feeder trade for the other two, each of the three trades has its own quota of substantive ranks up to W.O.I. In that, it is an example to its larger colleague.

The trade structure of the R.A.M.C. has been under continuous study for many years but more recently, and in greater detail, by this same A.M.D. Working Party formerly chaired by the Inspector of Medical Services (I.M.S.) then by O.I.C. Records, and in future once again by the I.M.S. in his dual capacity as Commandant, R.A.M.C. Training Centre.

The recommendation for technical status for State Registered Nurses stems from that working party. But so do various other proposed changes.

When is a nurse not a nurse? In my view Gentlemen, when he or she fails to fit into the accepted meaning of that term in civil life. For the majority of men an Army career ends at 40 years of age. They are then required to fit into a new environment, to take up civilian employment, already with a family to support. We would be failing in our duty to plan a career structure for the soldier if we did not take into account that after working for us for 22 years he is going to work as a civilian for someone else for 25 years, or until eligible for pension under the social security system.

It follows, therefore, that as far as possible our career structure in the R.A.M.C. should conform to the employments open in civil life in the range of occupations ancillary 
to medicine. I emphasise " as far as possible" because our basic trade of Medical Assistant, the soldier in the field, which will certainly be no smaller under the Working Party's proposals and which badly needs a new descriptive title, has no exact counterpart in civil life. Nevertheless, we have noted in Records an increasing number of enquiries from the National Health Service and from other medical organisations for Army trained men of this type for civilian employment, general administration, the managerial side of hospital house-keeping, and so on.

The Working Party proposes that certain trades shall be career linked and treated as a composite group for promotion purposes. The exact structure of each group, its specific quota of ranks, its known wastage and foreseen requirements for recruits are now being studied. The aim is to divide each group into two, those men who will serve in it for up to 9 or at most 12 years, and those who remain in it for the full 22 years or until commissioned. The shorter term group will either return to civil life, or will transfer within the R.A.M.C. to the general roll to complete a full Army career in

Table IV

Present trade groups

\begin{tabular}{|c|c|c|c|c|c|c|}
\hline & \multirow{2}{*}{ Group } & \multirow{2}{*}{ Trade } & \multirow{2}{*}{ Outline career } & \multicolumn{3}{|c|}{ Eligibility for commission } \\
\hline & & & & $\begin{array}{l}\text { N.M. } \\
\text { (Tech) }\end{array}$ & S.R.C. & $\begin{array}{l}\text { P.R.A.C. } \\
\text { (Q.M.) }\end{array}$ \\
\hline \multirow{5}{*}{ 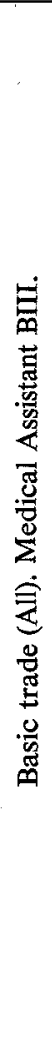 } & $\begin{array}{l}\text { Supervisory } \\
\text { Technical }\end{array}$ & $\begin{array}{l}\text { Public Health } \\
\text { Inspector }\end{array}$ & $\begin{array}{l}\text { S sgt on appointment } \\
\text {-W.O.II by time. } \\
\text { To W.O.I by selec- } \\
\text { tion within trade } \\
\text { only. }\end{array}$ & $\begin{array}{l}\text { W.O. } \\
+ \text { Yes }\end{array}$ & \multirow{5}{*}{$\begin{array}{l}\text { All } \\
\text { any } \\
\text { Rank }\end{array}$} & \multirow{5}{*}{$\begin{array}{l}\text { All } \\
\text { on } \\
\text { W.O.I } \\
\text { Roster }\end{array}$} \\
\hline & $\begin{array}{c}\text { Technical } \\
\text { trades }\end{array}$ & $\begin{array}{l}\text { Laboratory } \\
\text { Technician } \\
\text { Physiotherapist } \\
\text { Radiographer }\end{array}$ & $\begin{array}{l}\text { L cpl to sgt by time. } \\
\text { S sgt to W.O.I by } \\
\text { selection within own } \\
\text { trade only }\end{array}$ & $\begin{array}{l}\text { W.O. } \\
+ \text { Yes }\end{array}$ & & \\
\hline & $\begin{array}{l}\text { Non-Technical } \\
\text { trades 'A' } \\
\text { and 'B' }\end{array}$ & $\begin{array}{l}\text { Assistant Male } \\
\text { Nurse } \\
\text { Mental Nursing } \\
\text { Assistant } \\
\text { Special Treatment } \\
\text { Assistant } \\
\text { Operating Theatre } \\
\text { Technician } \\
\text { Storeman (Technical) } \\
\text { Dispenser } \\
\text { Hygiene Assistant } \\
\text { Clerk }\end{array}$ & $\begin{array}{l}\text { pte, L cpl, cpl, and } \\
\text { sgt-Employment } \\
\text { within own trade to } \\
\text { Class I. Promotion } \\
\text { on general roster by } \\
\text { selection. } \\
\text { sgt, S sgt. W.O.II and } \\
\text { W.O.I-Promotion } \\
\text { on general roster by } \\
\text { selection. Employ- } \\
\text { ment within own } \\
\text { trade or at regimen- } \\
\text { tal duties or mixture } \\
\text { of both }\end{array}$ & $\begin{array}{l}\text { State } \\
\text { Registered } \\
\text { Nurse. } \\
\text { W.O. + } \\
\text { Yes. } \\
\text { Stores } \\
\text { Technician. } \\
\text { W.O. + } \\
\text { Yes. } \\
\text { Dispenser } \\
\text { (if dual } \\
\text { qualified). }\end{array}$ & & \\
\hline & & Medical Assistant & $\begin{array}{l}\text { All employment at } \\
\text { regimental duties. } \\
\text { Promotion with gen- } \\
\text { eral roster. }\end{array}$ & & & \\
\hline & $\begin{array}{c}\text { Disrated } \\
\text { tradesmen }\end{array}$ & All & $\begin{array}{l}\text { Requalify in new } \\
\text { trade for promotion } \\
\text { in general roster. }\end{array}$ & & & \\
\hline
\end{tabular}


regimental employment. But unless warned to the contrary at this 9 or 12 year point that he has already reached his ceiling-and we must retain some hewers of wood and drawers of water-the long term intention is that every soldier who remains for the full 22 years shall have a reasonable prospect of becoming at least $\mathrm{S}$ sgt. or equivalent.

The present and proposed trade groups are illustrated in Tables IV and V, respectively.

Table V

Proposed trade groups

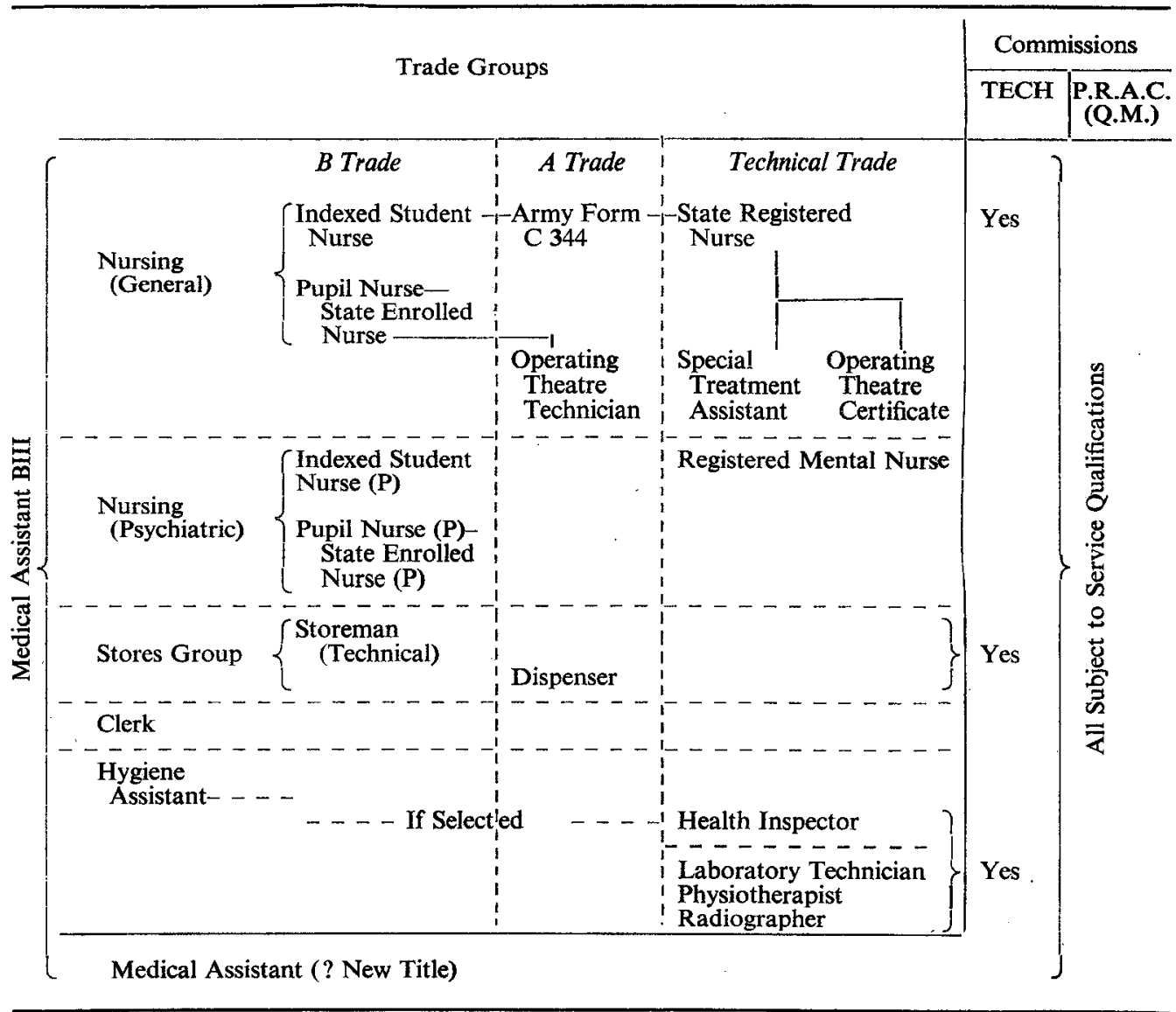

Apart from achieving at least the rank of S sgt. in whatever group he is employed the full career soldier should have a reasonable opportunity of attaining warrant and commissioned rank. It would be quite unfair if, other things being equal, the members of one trade group had a much greater chance of attaining a Permanent Regular Army (Quartermaster) Commission (P.R.A.C.(Q.M.)) than members of another group. Although, therefore, the opportunities for obtaining Non-Medical (Technical) Commissions (N.M.(Tech.)) or Special Regular Commissions (S.R.C.) may vary between groups, one of the main complications in working out the future trade structure is in how to ensure " a fair chance" for everybody when it comes to regular Q.M. commissions. 
We are unlikely to solve this problem just yet. One point I would like to make. Until now entry to the hypothetical roster of W.Os.I (for which the minimum requirement is 12 years adult service and from which all our regular Q.M. officers are selected)-has been either by actual appointment to the substantive rank of W.O.I, or by theoretical advancement to that rank immediately before the man next junior, if granted a short service or special regular commission before attaining W.O.I.

To illustrate this latter method which sounds more complicated than it is, consider a tradesman with a minimum of 12 years service who is promoted substantive W.O.II. He applies for and is appointed to a technical commission R.A.M.C. in his trade. His hypothetical seniority as W.O.I (a rank he has never held) will be decided by the date on which the next W.O.II below him attains that actual rank. When that next junior soldier attains W.O.I on the general roll of the Corps, all is very fair and above board. But with the introduction of small technical trades each with a complete rank spectrum up to and including W.O.I, and each with a different rate of advancement, a certain degree of unfairness can and does creep in.

Not only does the technician gain extra pay and promotion by time up to the rank of sgt., but, because his technical trade has acquired a reasonably generous quota of higher ranks, further advancement beyond sgt may be fairly rapid. This speed of promotion within the technical trade roll is enhanced by the fact that, once beyond any time-bar on discharge by purchase, some of its senior members are enticed to leave the service for well paid jobs in their technical specialities in the civilian health services or in industry at home or abroad. Public Health Inspectors, Laboratory Technicians and Physiotherapists are all open to such temptation. Their premature departures increase still further the speed of promotion and may well result (indeed have already resulted) in appointment to substantive W.O.I in a technical trade vacancy at an inordinately early stage in service.

As O.I.C. Records I believe it is quite wrong that in addition to all these advantages of pay and promotion, this same accelerated advancement to W.O.I, should also gain simultaneous entry to the roster for eligibility for P.R.A.C.(Q.M.). It is my contention therefore that up whatever promotion ladder a soldier climbs, his entry to the roster for consideration for Regular Q.M. must be standardised. The only fair way to standardise (since provision must be made for both early and late entrants to the Corps), is by length of adult service in addition to the rank qualification. I hope therefore that 1970 will see the introduction of this new system which will iron out one of the anomalies which the introduction of separate rolls has brought about.

\section{Conclusion}

Sir, you asked me to speak about careers for the R.A.M.C. and R.A.D.C. soldiers. This I have tried to do and to show that such reforms that we have seen in recent months and those others foreseen for the near future are for the benefit of the Service and of the individual soldier.

At this point I cannot over-estimate (and I make no apology for repeating myself) the importance of the opinions expressed on annual confidential reports by officers 
throughout the chain of reporting. Their recommendations are the lynch pin of the entire system. On their integrity the whole future outlook depends.

To obtain real satisfaction out of a job one must feel some sense of achievement. I would not be content, Sir, to write as the O.I.C. Records of your Corps without the knowledge firstly, that the lot of the good soldier (and there are many such) has been improved and secondly, that when I speak of careers, there are genuine and worthwhile careers in the Army still to be made in return for honest endeavour.

District Colonel T. \& A.V.R.

Lieutenant-Colonel N. MacLean, O.B.E., T.D., R.A.M.C. (R.A.R.O.), has been selected to fill the District Colonel's post in Yorkshire District, with effect from 1 May 1970.

His chief role will be to advise the District Commander on T. \& A.V.R. matters in peace, and will include supervision of cadres with special reference to their planning role for any sudden expansion of the Reserve if circumstances made this necessary. On mobilisation he is responsible for filling vacancies at the discretion of the Regional Military Commander (designate) at Regional or Sub-Regional level.

As such appointments are usually reserved for officers in the combatant arms, Lieutenant-Colonel MacLean's selection is exceptional and we offer him our congratulations. 